\title{
PRODUCTIVITY GROWTH IN FOOD CROP PRODUCTION IN IMO STATE, NIGERIA
}

\author{
C.E. ONYENWEAKU, I.N. NWACHUKWU ${ }^{1}$ and T.C. OPARA \\ Department of Agricultural Economics, Michael Okpara University of Agriculture, Umudike, \\ Abia State, Nigeria \\ ${ }^{1}$ Department of Agribusiness and Management, Michael Okpara University of Agriculture, Umudike, \\ Abia State, Nigeria \\ Corresponding author: ifnwachukwu@yahoo.com; nwachukwu.ifeanyi@mouau.edu.ng
}

(Received 4 May, 2010; accepted 2 September, 2010)

\begin{abstract}
Agriculture plays pivotal roles in Nigeria including food security, employment, foreign exchange earnings and poverty reduction. This study examined the growth in food crop productivity in Imo State in Nigeria with emphasis on the decomposition of total factor productivity (TFP) into technical progress, changes in technical and allocative efficiency and scale effects. A panel data set comprising 210 observations drawn over $2001-2007$ periods was used. Using the translog stochastic frontier production function, the decomposition components were computed. The results showed that TFP decreased through time, while technical change was negative, implying downward shift of the production frontier. As a major component, technical change was the main constraint to the achievement of high levels of TFP during the study period. The scale effect, which is generally bigger than technical change component shows that the sampled farms had not taken advantage of scale economies. Furthermore, the allocative efficiency had an average magnitude closer to the scale effect and points towards decreases in the efficiency with which production factors are allocated. This is an indication of a decline in technical efficiency. We suggest reforms in the Agricultural Development Programmes (ADPs) geared towards enhancing their capacity in extending novel technologies and innovations to farmers.
\end{abstract}

Key Words: Productivity decomposition, scale effect, allocative efficiency

\section{RÉSUMÉ}

L’agriculture joue un role primordial au Nigeria en terme de sécurité alimentaire, création d'emploi, génération de devises étrangères et la réduction de la pauvreté. Le but de cette étude était d'examiner la croissance en productivité des cultures vivrières dans l'Etat d'Imo au Nigéria sur base de la décomposition du facteur total de productivité (TFP) dans le progrès technique, les changements techniques et allocation efficiente et effets d'échelle. Un ensemble de données issues de 210 observations faites au cours de 2001-2007 était utilisé. L'usage aléatoire de la limite de fonction translog de production, la décomposition des composantes était calculée. Les résultats ont montré que la TFP avait décru avec le temps, alors que le changement technique était négative impliquant une baisse de la limite de production. En tant que composante majeur, le changement technique était la principale contrainte à l'accomplissement de niveaux élevés de TFP au cours de la période d'étude. L'effet d'echelle qui est généralement plus élevé que la composante du changement technique ont montré que les fermes échantiollonnées n'avaient pas jouis de l'avantage de l'économie d'échelle. En plus, l'efficience des allocations avait pris en moyenne une ampleur plus proche de l'effet d'échelle et tendait à décroître en terme d'efficience avec laquelle les facteurs de production sont alloués. Ceci fait montre d'une baisse en efficience technique. Pour ce faire, nous suggérons des réformes des Programmes de Développement Agricole en promouvant leur capacité d'extension de nouvelles technologies et innovations aux fermiers.

Mots Clés: Décompostion de production, effet d’échelle, allocation efficiente 


\section{INTRODUCTION}

Agriculture plays pivotal roles in economic development over the past several decades. These include food security, employment, foreign exchange earnings and poverty reduction (CBN, 1998; NPC, 2004). Despite the enormous contributions of agriculture to the Nigerian economy over the years, the sector has slipped into a system decline, particularly in the past three decades since the petroleum industry replaced the sector as the main earner of government revenue (NISER, 2004). As a result, productivity has been the major focus of agricultural research over the last century. With improvements in plant and animal genetics, research has paid off with major productivity gains such as the tripling of corn yield over the last 50 years (Njoku, 2005).

Ideally, productivity growth in the agricultural sector is considered important if the sector is to improve at a rate equal to or greater than the population growth rate to meet the demand for food and raw materials. Also, productivity performance in the agricultural sector is critical to improvement in the economic well being of the entire country (Alabi, 2005).

The general decline in agricultural productivity has translated into gross incapacitation of the sector in meeting the rising food demand and by extension led to perennial for instance food shortages, soaring food prices and massive importation ( Imodu, 2005; Onyenweaku and Nwaru, 2005). Tanko et al. (2006) averred that Nigeria's food deficient situation has been worsened by declining farm productivity owing to inefficient production techniques, poor resource base and declining soil productivity among others.

Although several reports (FAO, 2004; Dayo et al., 2008; Fakayode et al., 2008; Ebong et al., 2009) have attributed the low rates of agricultural production to low rates of technologies adoption and dependence on indigenous knowledge, such knowledge is considered inadequate given the increasing demand from agriculture. The need, therefore, for improved strategies becomes imperative.

To this end, a number of strategies have been advocated to address this situation.
Combinations of farm enterprises with the aim of increasing the level of farm resource and making efficient use of resources already committed to the food sub-sector was advocated by Tanko et al. (2006). Stabilisation policies to reduce inflation and subsidies in the form of cheap credit was suggested by Okoye (2006) to assist farmers in acquiring inputs. Onyenweaku and Nwaru (2005) opined the efficient utilisation of productive resources as ways of increasing productivity. This study examined productivity growth, its decomposition and rate of change in food crop production in Imo State in Nigeria.

\section{MATERIALS AND METHODS}

Study area. The study was conducted in Imo State in Nigeria which lies between latitude $5^{0} 10^{\prime}$ and $6^{\circ} 35^{\prime}$ North of the equator and between longitude $6^{0} 35^{\prime}$ and $7^{0} 31^{\prime}$ East of the Greenwich meridian. This is a tropical rainforest zone, located in the Southeastern zone of Nigeria. Imo State, one of the 36 states in Nigeria, has a population of about 3.934 million people disaggregated into 2.032 males and 1.903 females in 2006 (NPC, 2007). The state is divided into 27 administrative units called local government areas which are grouped into 3 agricultural zones of Owerri, Okigwe and Orlu.

Agriculture is the predominant occupation of the people, for almost all the farm families either as primary or secondary occupation. The ecological zone favours the growing of tree crops, roots and tubers, cereals, vegetables and nuts. These crops are grown in small holder plots usually in mixtures of at least two simultaneous crops (Imo ADP, 1994).

Data collection. The study employed farm level data elicited from the ADP's yearly survey for the period, 2001-2007 using past questionnaires. The ADP annually collects micro-economic data from a sample of agricultural holdings in Imo State. Although the collected data were based on individual responses, state and zonal level aggregates were used to define some variables such as land, labour and capital. The sample comprised 210 observations that constituted the panel data used by the study. 
Data analysis. This study followed the primal approach proposed by Kumbhakar (1990) in which total factor productivity (TFP) growth was decomposed into technical progress, changes in technical and allocative efficiency and scale effects. In order to estimate decomposition of productivity growth, a stochastic frontier production function approach was employed. A deterministic frontier production function is specified as:

$Y_{i t}=f\left(X_{i t}, t ; \beta\right) \cdot \exp \left(-u_{i t}\right)$

where $\gamma$ is the scalar output of the $i^{\text {th }}$ farm ( $\mathrm{i}=$ $1, \ldots, N)$ in period $t(t=1, \ldots \ldots, T)$,

$f\left(X_{i t}, t ; \beta\right)$ is the deterministic kernel of a stochastic production frontier with technology parameter vector â to be estimated, $X=\left(X_{1}, \ldots, X_{N}\right) \geq 0$ is an input vector, $\mathrm{t}$ is a time trend serving as a proxy for technical change, and $\mathrm{u} \geq 0$ represents output - oriented technical inefficiency. Technical efficiency is then defined by

$$
\begin{aligned}
& \mathrm{y}_{\mathrm{it}}=\exp \left(-\mathrm{u}_{\mathrm{it}}\right) \leq 1 . \\
& \left(\mathrm{X}_{\mathrm{it}}, \mathrm{t} ; \beta\right)
\end{aligned}
$$

The technical efficiency term can be either fixed or random and the specification in Equation (1) allows technical efficiency to vary over time. A primal measure of the rate of technical change is provided by

$$
\Delta \mathrm{TC}=\underset{\mathrm{t}}{\operatorname{In} \mathrm{f}}\left(\mathrm{X}_{\mathrm{it}}, \mathrm{t} ; \beta\right)
$$

where $\Delta \mathrm{TC}$ is positive if the exogenous technical change shifts the production frontier upward, given the inputs. A primal measure of the rate of change in technical efficiency is given as

$$
\Delta \mathrm{TE}=- \text { “u }
$$

where $\Delta \mathrm{TE}$ is negative if technical efficiency declines through time. $\Delta$ TE can be interpreted as the rate at which a producer moves toward or away from the production frontier, other things kept constant.

To operationalise the model, the following was specified:
$\mathrm{TFP}=\Delta \mathrm{TC}+(\varepsilon-1) \Sigma\left(\varepsilon_{\mathrm{n}} / \varepsilon\right) \mathrm{X}_{\mathrm{n}}+\Sigma\left[\left(\varepsilon_{\mathrm{n}} / \varepsilon\right)-\mathrm{S}_{\mathrm{n}}\right] \mathrm{X}_{\mathrm{n}}$ $+\Delta \mathrm{TE}$

where

TFP = Total Factor Productivity;

$\Delta \mathrm{TC}=$ Technical Change Component;

$\Delta \mathrm{TE}=$ Technical efficiency change component; $(\varepsilon-1) \Sigma\left(\varepsilon_{\mathrm{n}} / \varepsilon\right) \mathrm{X}_{\mathrm{n}}=$ Scale effect component; $\Sigma\left[\left(\varepsilon_{\mathrm{n}} / \varepsilon\right)-\mathrm{S}_{\mathrm{n}}\right] \mathrm{X}_{\mathrm{n}}{ }^{\mathrm{n}}=$ Allocative efficiency change component; and

$\mathrm{S}_{\mathrm{n}}=$ Observed expenditure share of input.

In estimating the technical efficiency change, the following Translog stochastic frontier model was employed in line with Fan (1991); Mazvimavi (2002); and Nwachukwu and Onyenweaku (2007). It was specified as:

In $Y_{\text {it }}=\beta_{0}+\beta_{1}$ In $X_{1}+\beta_{2}$ In $X_{2}+\beta_{3}$ In $X_{3}+\beta_{4}$ In $X_{4}$ $+\beta_{5} \operatorname{In} \mathrm{t}+0.5 \beta_{6} \operatorname{In}\left(\mathrm{X}_{1}\right)^{2}+0.5 \beta_{7} \operatorname{In}\left(\mathrm{X}_{2}\right)^{2}+0.5 \beta_{8}$ In $\left(X_{3}\right)^{2}+0.5 \beta_{9} \operatorname{In}\left(X_{4}\right)^{2}+0.5 \beta_{10} \operatorname{In}(t)^{2}+\beta_{11}\left(X_{1}\right)$ In $\left(X_{2}\right)+\beta_{12} \operatorname{In}\left(X_{1}\right) \operatorname{In}\left(X_{3}\right)+\beta_{13} \operatorname{In}\left(X_{1}\right) \operatorname{In}\left(X_{4}\right)+\beta_{14}$ $\operatorname{In}\left(X_{1}\right) \operatorname{In}(t)+\beta_{15} \operatorname{In}\left(X_{2}\right) \operatorname{In}\left(X_{3}\right)+\beta_{16} \operatorname{In}\left(X_{2}\right) \operatorname{In}\left(X_{4}\right)$ $+\beta_{17} \operatorname{In}\left(X_{2}\right) \operatorname{In}(t)+\beta_{18} \operatorname{In}\left(X_{3}\right) \operatorname{In}\left(X_{4}\right)+\beta_{19} \operatorname{In}\left(X_{3}\right)$ $\operatorname{In}(\mathrm{t})+\beta_{20} \operatorname{In}\left(\mathrm{X}_{4}\right)(\mathrm{t}-)+\mathrm{V}_{\mathrm{i}}-\mathrm{U}_{\mathrm{i}}$

where In = Natural logarithm

The subscripts $\mathrm{i}$ and $\mathrm{t}$ represent the $\mathrm{i}^{\text {th }}$ sample farmer in the period $t$.

$\mathrm{Y}_{\text {it }}=$ Total value of output in Naira of the $\mathrm{i}^{\text {th }}$ farmer in the period $\mathrm{t}$;

$\mathrm{X}_{1}=$ Farm size measured as total land area in hectares;

$\mathrm{X}_{2}=$ Quantity of fertiliser used in kg;

$\mathrm{X}_{3}=$ Labour in man days used in production;

$\mathrm{X}_{4}=$ Capital Inputs (values of farm implements measured in Nigerian Naira);

$\mathrm{t}=$ The period of time in years the study was conducted $(\mathrm{t}=1 \ldots .7)$;

$\beta_{0}=$ Intercept;

$\beta_{1}-\beta_{20}=$ Coefficients estimated;

$\mathrm{V}_{\mathrm{it}}=$ Random noise error component; and

$\mathrm{U}_{\mathrm{it}}=$ Technical efficiency error component.

Given that the study interest centered on the estimation of productivity change, the estimates of $\Delta \mathrm{TC}, \Delta \mathrm{TE}, \varepsilon_{\mathrm{n}}$ and $\varepsilon$ were derived by means of: 


$$
\begin{aligned}
& \Delta \mathrm{TC}=\beta_{\mathrm{t}}+\beta_{\mathrm{it}} \mathrm{t}+\Sigma \beta_{\mathrm{nt}} \operatorname{InX}_{\mathrm{nit}} \\
& \Delta \mathrm{TE}=\mathrm{U}_{\mathrm{i}} \cdot c_{\zeta} \cdot \exp (-c ̧[\mathrm{t}-\mathrm{T}]) \\
& \varepsilon_{\mathrm{n}}=\beta_{\mathrm{n}}+0.5 \Sigma \beta_{\mathrm{nk}} \operatorname{InX}_{\mathrm{kit}}+0.5 \beta_{\mathrm{nt}} \mathrm{n}=1 \ldots \mathrm{N} . \\
& \varepsilon=\Sigma\left[\beta_{\mathrm{n}}+0.5 \Sigma \beta_{\mathrm{nk}} \operatorname{InX}_{\mathrm{kit}}+0.5 \beta_{\mathrm{nt}} \mathrm{t}\right] \ldots
\end{aligned}
$$

Empirically, technical change $(\Delta \mathrm{TC})$, technical efficiency $(\Delta \mathrm{TE})$, elasticity of $\mathrm{n}$ output with respect to each input $\left(\varepsilon_{\mathrm{n}}\right)$ and the scale elasticity $(\beta)$ can be obtained empirically as follows:

$\Delta \mathrm{TC}=\beta_{5}+\beta_{10}+\beta_{1} \operatorname{In} \mathrm{X}_{1}+\beta_{2} \operatorname{In} \mathrm{X}_{2}+\beta_{3} \operatorname{In} \mathrm{X}_{3}+\beta_{4}$ $\operatorname{In} \mathrm{X}_{4}$

$\Delta \mathrm{TE}=\hat{\mathrm{U}} \cdot c ̧ \cdot \mathrm{e}^{-c(t-T)}$

$\varepsilon X_{1}=\beta_{1}+0.5 \beta_{6}$ In $X_{1}+0.5 \beta_{11} \operatorname{InX}_{2}+0.5 \beta_{12}$ In $X_{3}$ $+0.5 \beta_{13} \operatorname{In} X_{4}+0.5 \beta_{14} \mathrm{t}$

$\varepsilon X_{2}=\beta_{2}+0.5 \beta_{7} \operatorname{In} X_{2}+0.5 \beta_{11} \operatorname{InX}_{1}+0.5 \beta_{15} \operatorname{InX}_{3}+$ $0.5 \beta_{16}$ In $X_{4}+0.5 \beta_{17} \mathrm{t}$

$\varepsilon X_{3}=\beta_{3}+0.5 \beta_{8}$ In $X_{3}+0.5 \beta_{12}$ InX $X_{1}+0.5 \beta_{15}$ In $X_{2}$ $+0.5 \beta_{18} \operatorname{In} X_{4}+0.5 \beta_{19} \mathrm{t}$

$\varepsilon X_{4}=\beta_{1}+0.5 \beta_{6} \operatorname{In} X_{1}+0.5 \beta_{11} \operatorname{InX} X_{2}+0.5 \beta_{12} \operatorname{In} X_{3}+$ $0.5 \beta_{13}$ In $X_{4}+0.5 \beta_{14}$ t.

$\varepsilon=\varepsilon X_{1}+\varepsilon X_{2}+\varepsilon X_{3}+\varepsilon X_{4}$

where:

$\varepsilon \mathrm{X}_{1}=$ elasticity of output with respect to farm size;

$\varepsilon \mathrm{X}_{2}=$ elasticity of output with respect to fertiliser;

TABLE 1. Estimation of the total factor productivity changes

\begin{tabular}{llllll}
\hline Year & $\Delta \mathrm{TC}$ & $\varepsilon-1 \Sigma\left(\varepsilon_{\mathrm{n}} / \varepsilon\right) \mathrm{X}_{\mathrm{n}}$ & $\Sigma\left[\left(\varepsilon_{\mathrm{n}} / \varepsilon\right)-\mathrm{S}_{\mathrm{n}}\right] \mathrm{X}_{\mathrm{n}}$ & $\Delta \mathrm{TE}$ & $\mathrm{TFP}$ \\
\hline 2001 & -2.669 & -1.370 & -0.015 & 0.469 & -3.585 \\
2002 & -2.693 & -0.017 & -0.027 & 0.460 & -2.223 \\
2003 & -2.986 & 0.640 & -0.267 & 0.448 & -1.872 \\
2004 & -3.132 & 0.018 & 0.095 & 0.416 & -2.798 \\
2005 & -3.150 & 0.044 & -0.046 & 0.356 & -3.398 \\
2006 & -2.536 & 0.203 & 0.015 & 0.530 & -1.788 \\
\hline
\end{tabular}

Source: Computed from field survey Data and Frontier 4.1 Output $\varepsilon \mathrm{X}_{3}=$ elasticity of output with respect to labour input;

$\varepsilon \mathrm{X}_{4}=$ elasticity of output with respect to capital input; and

$\varepsilon \quad=$ scale effect.

\section{RESULTS AND DISCUSSION}

The mean TFP growth rates decreased through time at an increasing rate from $3.5 \%$ in 2001 to $1.7 \%$ in 2007 (Table 1). This conforms to the findings of several workers (Imodu, 2005; Njoku, 2005; Onyenweaku and Nwaru, 2005; Tanko et performance has declined in Nigeria. It has been noted also that agricultural productivity has slipped into a system decline, particularly in the past three decades since the petroleum industry replaced the sector as the main earner of government revenue and foreign exchange earnings (NISER, 2004).

TFP growth decomposed into technical change, scale effect, technical efficiency and allocative efficiency (Table 1 ) revealing that the technical change is negative for the period change shifts the production frontier downward given the inputs. This could be as a result of inefficient production techniques, poor resource base, declining soil productivity, predominance of primitive techniques of agricultural production, inadequate supply of credit, low capital investment, use of crude implements to mention but a few (Dayo et al., 2008; Onyenweaku and Nwaru, 2005). It further implies that technical change has been the main constraint to the achievement of high levels of TFP during the al., 2006) which confirmed that agricultural studied. This implies that the exogenous technical 
reference period. This result is consistent with the findings of Nkamleu (2004), Ogunyinka and Langemeier (2004) who had a similar outcome. Technical efficiency was drawn from Table 2.

The scale effect, which was generally bigger than technical change, showed that the sampled farms on the average had not taken advantage of scale economies, though it fluctuated throughout the period of analysis. By implication, larger farms had no advantage over the small ones in the study area. This consolidates the findings of Owualah (1999) and Sanusi (2003) which admitted that small scale enterprises enjoy a competitive advantage over large scale enterprises and the existence of an inverse relationship between firm size and firm growth in developing countries.

The allocative efficiency had an average magnitude closer to the scale effect and points towards decreases in the efficiency with which production factors are allocated, though it fluctuated through time. Generally, allocative efficiency captures either deviation of input prices from the value of their marginal products or departure of marginal rate of technical substitution from the ratio of input prices (Mazvimavi, 2002). The rate of change of technical efficiency, the most relevant component in the TFP growth decomposition, indicated a decline in technical efficiency. Given that technical efficiency is time varying and inefficiency exists, the decomposition of TFP implies that $\triangle \mathrm{TE}$ affects TFP growth.

On the basis of the findings, the following remedial measures are suggested: Government should embark on reforms of the ADPs with a bid to enhancing their capacity in extending novel technologies and innovations to farmers. This is imperative since technical change is negative.

TABLE 2. Maximum likelihood estimates of the Stochastic Translog Production Function

\begin{tabular}{|c|c|c|c|c|}
\hline Production factor & Parameter & Coefficient & Standard error & t-value \\
\hline Constant term & $\beta_{0}$ & 11.09 & 0.718 & $15.438 * \star \star$ \\
\hline Farm size & $\beta_{1}$ & 0.525 & 0.209 & $2.504^{\star \star \star}$ \\
\hline Fertiliser & $\beta_{2}$ & -0.185 & 0.065 & $-2.839 * \star \star$ \\
\hline Labour & $\beta_{3}$ & 0.017 & 0.218 & $7.915^{\star \star \star}$ \\
\hline Capital & $\beta_{5}$ & -0.614 & 0.255 & $-2.410^{\star *}$ \\
\hline Time & $\beta_{5}$ & 0.697 & 0.495 & 1.409 \\
\hline Farm size ${ }^{2}$ & $\beta_{6}$ & -0.282 & 0.037 & 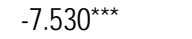 \\
\hline Fertiliser $^{2}$ & $\beta_{7}$ & -0.022 & 0.017 & -1.288 \\
\hline Labour $^{2}$ & $\beta_{8}$ & 0.035 & 0.006 & $5.710^{\star \star \star}$ \\
\hline Capital$^{2}$ & $\beta_{9}$ & 0.058 & 0.022 & $2.678^{* \star \star}$ \\
\hline Time $^{2}$ & $\beta_{10}$ & -0.999 & 0.262 & $-3.815^{\star \star \star}$ \\
\hline Farm size $x$ fertiliser & $\beta_{11}$ & 0.03 & 0.021 & 1.437 \\
\hline Farm size $x$ labour & $\beta_{12}$ & 0.044 & 0.032 & 1.381 \\
\hline Farm size $x$ capital & $\beta_{13}^{12}$ & -0.105 & 0.026 & $-4.063^{\star \star \star}$ \\
\hline Farm size $x$ time & $\beta_{14}$ & 0.119 & 0.082 & 1.46 \\
\hline Fertiliser $x$ labour & $\beta_{15}$ & -0.077 & 0.024 & $-3.233^{\star \star \star}$ \\
\hline Fertiliser $x$ capital & $\beta_{16}$ & 0.032 & 0.055 & $2.075^{\star \star}$ \\
\hline Fertiliser $x$ time & $\beta_{17}$ & 0.236 & 0.307 & $7.682^{\star \star \star}$ \\
\hline Labour x capital & $\beta_{18}$ & -0.069 & 0.179 & $-3.883^{\star \star \star}$ \\
\hline Labour x time & $\beta_{19}$ & -0.511 & 0.122 & $-4.197^{\star \star \star}$ \\
\hline Capital x time & $\beta_{20}$ & 0.235 & 0.033 & $7.100^{\star \star \star}$ \\
\hline \multicolumn{5}{|l|}{ Diagnostic statistics } \\
\hline Log-likelihood function & & -223.041 & & \\
\hline Total variance $\left(\mathrm{s}^{2}\right)$ & & 2.945 & 0.169 & $17.592^{\star \star \star}$ \\
\hline Variance ratio (g) & & 0.999 & 0 & 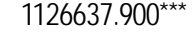 \\
\hline LR Test & & 43.76 & & \\
\hline
\end{tabular}

Source: Computed from Frontier 4.1 MLE/ Survey data

Note: *** ${ }^{* *}$, * indicates statistically significant at 1.0, 5.0 and 10.0\% probability respectively 


\section{REFERENCES}

Alabi, I. 2005. The determinants of agricultural productivity in Nigeria. Food, Agriculture and Environment Journal 3(2):78 - 82.

Central Bank of Nigeria (CBN), 1998. The Challenging Structure of Nigerian Economy and Implications for Development. The Research Department, Abuja, Nigeria.

Ebong, V.O., Okoro, U.S. and Effiong, E.O. 2009. Determinants of technical efficiency of urban farming in Uyo Metropolis of Akwa Ibom State, Nigeria. Journal of Agriculture and Social Sciences 5:89-92.

Dayo, P., Nkonya, E., Pander, J. and Oni, O.A. 2008. Constraints to Increasing Agricultural Productivity in Nigeria. Brief No.4, International Food Policy Research Institute, Washington D C, USA.

Fakayode, S.B., Babatunde, R.O. and Ajao, R. 2008. Productivity analysis of cassava-based production systems in the Guinea savannah: Case study of Kwara State, Nigeria. American - Eurasian Journal of Scientific Research 3(1):33 - 39

Fan, S. 1991. Effects of technological changes and institutional reform on production growth in Chinese agriculture. American Journal of Agricultural Economics 73:266 - 275.

FAO. 2004. Production Year Book, Vol. 40. Food and Agriculture Organization of the United Nations. FAO, Rome, Italy.

Imodu, P.B. 2005. Government policies towards the sustainability rebirth in Nigeria: Challenges and opportunities. Proceedings of the $39^{\text {th }}$ Conference of the Agricultural Society of Nigeria held in Benin, Edo State, Nigeria. pp. 31 - 35.

Imo State Agricultural Development Programme (Imo ADP) 1994. Crop area and yield survey (CAYS). Summary report. Owerri, Imo State, Nigeria.

Kumbhakar, S.C. 1990. Production frontiers, panel data and time varying technical inefficiency. Journal of Econometrics 46:201 - 211.

National Institute for Social and Economic Research (NISER), 2004. Review of Nigerian Development 2001/2002. Understanding poverty in Nigeria: Ibadan, NISER.
National Planning Commission (NPC), 2004. National Economic Empowerment and Development Strategy (NEEDS). National Planning Commission, Abuja, Nigeria.

National Population Commission (NPC) 2007. Details of the breakdown of the national and state provincial population totals 2006 census. Federal Republic of Nigeria Official Gazette 94(24):1-26.

Njoku, M.E. 2005. Effect of agricultural productivity on comsumption, nutrition and health status of rural households in Abia State, Nigeria. PhD. Dissertation, Department of Agricultural Economics, Michael Okpara University of Agriculture, Umudike, Abia State, Nigeria.

Nkamleu, G.B. 2004. Productivity growth, technical progress and efficiency change in African agriculture. African Development Bank Research 008, Blackwell Publishing Ltd, Oxford, UK.

Nwachukwu, I.N. and Onyenweaku, C.E. 2007. Economic efficiency of Fadama Telfairia production in Imo State, Nigeria: A translog profit function approach. Journal of Agricultural Research and Policies 2(4):8793.

Okoye, B.C. 2006. Efficiency evaluation of smallholder cocoyam production in Anambra State, Nigeria. An M.Sc Thesis, Department of Agricultural Economics, Michael Okpara University of Agriculture, Umudike, Abia State, Nigeria.

Onyenweaku, C.E. and Nwaru, J.C. 2005. Application of stochastic frontier production function to the measurement of technical efficiency in food crop production in Imo State, Nigeria. The Nigerian Agricultural Journal 36:1 - 2.

Owualah, S.I. 1999. Entrepreneurship in small business firm. GMAG Investment Educational Publishers, Ikeja, Lagos , Nigeria.

Sanusi, J.O. 2003. Overview of Government efforts in the development of SME's and the emergence of small and medium industry equity investment scheme (SMIEIS) Organized by the Bankers Committee and Lagos Chambers of Commerce and Industry (LCCI) Lagos on $15^{\text {th }}$ June. 
Tanko, L., Onyenweaku, C.E. and Nwosu, A.C. 2006. Optimum crop combination under limited resource condition: A micro level study in
Yauri, Kebbi State, Nigeria. The Nigerian Agricultural Journal 37:1 -10. 